\title{
Effect of magnesium deficiency on various mineral concentrations in rat liver.
}

\section{$\operatorname{AUTHOR}(\mathrm{S}):$}

Kim, Ki Hyun; Ishizaki, Natsumi; Iguchi, Erika;

Funaba, Masayuki; Matsui, Tohru

\section{CITATION:}

Kim, Ki Hyun ... [et al]. Effect of magnesium deficiency on various mineral concentrations in rat liver.. Biological trace element research 2011, 144(1-3): 865-871

\section{ISSUE DATE:}

2011-12

URL:

http://hdl.handle.net/2433/152370

\section{RIGHT:}

The final publication is available at www.springerlink.com; This is not the published version. Please cite only the published version.; この論文 は出版社版でありません。引用の際には出版社版をご確認ご利用くだ さい。 


\section{Effect of magnesium deficiency on various mineral concentrations in rat liver}

Ki Hyun Kim, Natsumi Ishizaki, Erika Iguchi, Masayuki Funaba, Tohru Matsui*

Division of Applied Biosciences, Graduate School of Agriculture, Kyoto University, Kyoto 606-8502, Japan

Running title: Effect of magnesium deficiency in rat liver

* Corresponding Author: Tohru Matsui, PhD.

Division of Applied Biosciences

Kyoto University Graduate School of Agriculture

Kyoto 606-8502, Japan.

Tel: 81-75-753-6056

Fax: 81-75-753-6344

Email: matsui@kais.kyoto-u.ac.jp 


\begin{abstract}
Magnesium (Mg) deficiency is well known to affect metabolism of some trace minerals. We investigated the effect of $\mathrm{Mg}$ deficiency on hepatic concentration of various minerals in rats. Twelve 5-week-old male rats were divided into the groups given a control diet and an $\mathrm{Mg}$ deficient diet. After 4-week, liver sample was collected from each rat. The concentrations of 36 minerals were simultaneously determined by a semiquantitative method of inductively coupled plasma-mass spectrometry (ICP-MS). The semiquantitative analysis showed that Mg deficiency significantly increased iron $(\mathrm{Fe})$, copper $(\mathrm{Cu})$, zinc $(\mathrm{Zn})$, gallium $(\mathrm{Ga})$, yttrium $(\mathrm{Y})$, zirconium $(\mathrm{Zr})$, molybdenum (Mo), rhodium (Rh), silver ( $\mathrm{Ag})$, and barium (Ba) concentrations, and significantly decreased scandium $(\mathrm{Sc})$ and niobium $(\mathrm{Nb})$ concentrations in rat liver. Then, hepatic $\mathrm{Fe}, \mathrm{Cu}, \mathrm{Zn}, \mathrm{Sc}, \mathrm{Zr}$, and $\mathrm{Mo}$ concentrations were quantitatively measured, which indicated the similar effects as observed by the semiquantitative analysis. Additionally, the semiquantitative measurements of these minerals were highly correlated to these measurements with the quantitative method, but the measurements were not completely consistent between these analyses. The present study is the first research indicating the changes of hepatic $\mathrm{Ga}, \mathrm{Y}, \mathrm{Zr}, \mathrm{Mo}, \mathrm{Rh}, \mathrm{Ag}, \mathrm{Ba}, \mathrm{Sc}$, and $\mathrm{Nb}$ concentrations in Mg-deficient rats. The present study also indicates that the semiquantitative analysis with ICP-MS is a valid method for screening analysis to investigate various mineral concentrations in animal tissues.
\end{abstract}

Keywords: ICP-MS, liver, magnesium deficiency, trace mineral 


\section{Introduction}

Minerals often compete with each other for absorption in the intestine and for distribution in tissues and organs; the deficiency or excess of some minerals disturbs the metabolism of other minerals and results in changes of mineral concentration in blood and tissues [1-3].

Many studies have shown the influence of magnesium $(\mathrm{Mg})$ deficiency on mineral metabolism in the rats as follows. Kimura and Itokawa [4] reported that Mg deficiency increased hepatic iron ( $\mathrm{Fe})$ and zinc $(\mathrm{Zn})$ concentrations; several other researchers also indicated that high $\mathrm{Fe}[5,6]$ and high $\mathrm{Zn}$ [7] concentrations in the liver of Mg-deficient rats. Kimura and Itokawa [4] showed that $\mathrm{Mg}$ deficiency decreased hepatic copper $(\mathrm{Cu})$, but another group reported high $\mathrm{Cu}$ concentration in the liver of $\mathrm{Mg}$-deficient rats [8]. Although $\mathrm{Mg}$ deficiency is known to affect some mineral concentrations in tissues as mentioned above, the effect of Mg deficiency on the concentrations of many other minerals remains to be clarified.

Inductively coupled plasma-mass spectrometry (ICP-MS) is a technique for an accurate and precise trace element analysis. It is suitable for multielement analysis because of the simplicity of the spectra, the excellent detection limits, and the large linear dynamic range. The semiquantitative analysis using ICP-MS simultaneously provides approximate concentrations of many trace elements in one sample; this method is not necessary to specify the individual elements to be determined because ICP-MS can measure the entire mass spectrum, and then a software automatically corrects for isotopic interferences and interfering molecular species, producing a comprehensive report which lists each element present in the sample along with its concentration [9].

In the present study, we investigated the effect of $\mathrm{Mg}$ deficiency on various mineral concentrations in rat liver using a semiquantitative method of ICP-MS and its validity was confirmed by comparing semiquantitative and quantitative measurements in some minerals. 


\section{Materials and Methods}

Animals and Diets

Twelve 5-week-old male Sprague-Dawley rats were purchased from SLC Japan (Shizuoka, Japan) and cared for according to the Guide for the Care and Use of Laboratory Animals (Animal Care Committee, Kyoto University). The animals were individually housed in stainless steel cages in a temperature-, humidity- and light-controlled room $\left(24^{\circ} \mathrm{C}, 60 \%, 12\right.$ hour light/ dark cycle). All rats were fed a control diet (AIN-93G diet [10]) for 5-d adaptation period, followed by feeding either the control diet or a low-Mg diet, AIN-93G-based diet with mineral mixture (AIN-93G-MX [10]) modified to exclude magnesium oxide. The $\mathrm{Mg}$ concentration was $49.6 \mathrm{mg} / 100 \mathrm{~g}$ and $4.2 \mathrm{mg} / 100 \mathrm{~g}$ in the control diet and the low-Mg diet, respectively. The control rats were pair-fed to match the intake of the rats given low-Mg diet. All rats were allowed free access to demineralized water. After 4-week feeding trial, the rats were sacrificed by blood collection from the abdominal aorta under isofluran anesthesia, and the liver was collected.

Sample Collection and Analyses

A $0.5 \mathrm{~g}$ of liver sample from each rat was digested in a microwave high-pressure resolve device (ETHOS D, Milestone General, Japan) with $10 \mathrm{~mL}$ of trace-element grade concentrated nitric acid (Wako, Osaka, Japan). The digested sample was diluted to $50 \mathrm{~mL}$ by demineralized water.

We measured mineral concentrations in the liver sample by a quadrupole ICP-MS (Elan 6000, Perkin Elmer, USA) with a semiquantitative calculation program (TotalQuant III, Perkin Elmer, USA). We measured 36 minerals, i.e., $\mathrm{Mg}$, aluminum (Al), silicon ( $\mathrm{Si}$ ), phosphorus $(\mathrm{P})$, sulfur $(\mathrm{S})$, chlorine $(\mathrm{Cl})$, scandium $(\mathrm{Sc})$, titanium $(\mathrm{Ti})$, vanadium $(\mathrm{V})$, chromium $(\mathrm{Cr})$, manganese $(\mathrm{Mn}), \mathrm{Fe}$, cobalt $(\mathrm{Co})$, nickel (Ni), $\mathrm{Cu}, \mathrm{Zn}$, gallium (Ga), germanium (Ge), arsenic (As), rubidium (Rb), strontium ( $\mathrm{Sr}$ ), yttrium $(\mathrm{Y})$, zirconium $(\mathrm{Zr})$, niobium $(\mathrm{Nb})$, molybdenum $(\mathrm{Mo})$, ruthenium $(\mathrm{Ru})$, rhodium $(\mathrm{Rh})$, palladium $(\mathrm{Pd})$, silver $(\mathrm{Ag})$, cadmium $(\mathrm{Cd})$, tin $(\mathrm{Sn})$, antimony $(\mathrm{Sb})$, iodine $(\mathrm{I})$, cesium $(\mathrm{Cs})$, barium 
$(\mathrm{Ba})$, and lead $(\mathrm{Pb})$.

We also measured $\mathrm{Sc}\left({ }^{45} \mathrm{Sc}\right), \mathrm{Zr}\left({ }^{90} \mathrm{Zr}\right)$, and $\mathrm{Mo}\left({ }^{98} \mathrm{Mo}\right)$ concentrations in the liver sample with the quantitative method of ICP-MS (Elan 6000, Perkin Elmer, USA) and $\mathrm{Fe}, \mathrm{Zn}$, and $\mathrm{Cu}$ concentrations with an atomic absorption spectrophotometer (AA-6600F; Shimadzu, Kyoto, Japan). Dietary Mg concentration was also determined by the atomic absorption spectrophotometer after the nitric-acid digestion. Procedural accuracy of the metal analyses was evaluated by spiking a normal rat liver sample with respective standard solution. Recoveries for $\mathrm{Fe}, \mathrm{Cu}, \mathrm{Zn}, \mathrm{Sc}, \mathrm{Zr}$, and Mo were 102.8\%, $99.9 \%, 103.7 \%, 99.7 \%, 100.8 \%$, and $101.8 \%$, respectively. The following coefficients of variation were found: $\mathrm{Fe}, 3.0 \%$; $\mathrm{Cu}, 2.4 \%$; $\mathrm{Zn}, 3.8 \%$; Sc, $2.6 \%$; $\mathrm{Zr}, 2.7 \%$; and $\mathrm{Mo}, 1.3 \%$.

\section{Statistical Analyses}

Differences between the control group and the Mg-deficient group were evaluated by Student's ttest. Correlation between the semiquantitative measurements and the quantitative measurements was also analyzed. Statistical significance was considered to be $P<0.05$.

\section{Results and Discussion}

$\mathrm{Mg}$ deficiency is well known to develop increase of inflammation response and decline of immune function $[11,12]$, and skin lesion is a typical sign of $\mathrm{Mg}$ deficiency in rats [13]. The rats given low-Mg diet showed skin lesions in the ears and the tail from day 3, but no skin lesion was observed in the control group over all period (data not shown). Thus the rats given the low-Mg diet were considered as $\mathrm{Mg}$ deficient.

The semiquantitative analysis indicated that the hepatic concentrations of 12 minerals in 36 minerals were significantly different between the control group and the Mg deficient group (Table 1); the Mg-deficient group had higher concentrations of $\mathrm{Fe}(P<0.01), \mathrm{Cu}(P<0.01), \mathrm{Zn}(P<0.01), \mathrm{Ga}$ $(P<0.05), \mathrm{Y}(P<0.05), \mathrm{Zr}(P<0.01), \mathrm{Mo}(P<0.01), \mathrm{Rh}(P<0.05), \mathrm{Ag}(P<0.01)$, and $\mathrm{Ba}(P<0.05)$, 
and conversely had lower concentrations of $\mathrm{Sc}(P<0.05)$ and $\mathrm{Nb}(P<0.05)$ in the liver. The $\mathrm{Mg}$ deficiency did not affect hepatic concentrations of $\mathrm{Mg}, \mathrm{Al}, \mathrm{Si}, \mathrm{P}, \mathrm{S}, \mathrm{Cl}, \mathrm{Ti}, \mathrm{V}, \mathrm{Cr}, \mathrm{Mn}, \mathrm{Co}, \mathrm{Ni}, \mathrm{Ge}, \mathrm{As}$, $\mathrm{Rb}, \mathrm{Sr}, \mathrm{Ru}, \mathrm{Pd}, \mathrm{Cd}, \mathrm{Sn}, \mathrm{Sb}, \mathrm{I}, \mathrm{Cs}$, and Pb.

Generally, Mg deficiency did not affect hepatic concentrations of alkali metals, metalloids, halogens and nonmetallic elements. Magnesium deficiency increased some essential mineral concentrations, i.e., $\mathrm{Fe}, \mathrm{Cu} 、 \mathrm{Zn}$, and $\mathrm{Mo}$, and nonessential minerals such as $\mathrm{Ga}, \mathrm{Y}, \mathrm{Zr}, \mathrm{Rh}, \mathrm{Ag}$, and $\mathrm{Ba}$, but decreased nonessential minerals, $\mathrm{Sc}$ and $\mathrm{Nb}$ in rat liver.

We quantitatively determined hepatic $\mathrm{Fe}, \mathrm{Cu}, \mathrm{Zn}, \mathrm{Sc}, \mathrm{Zr}$, and Mo concentrations. The quantitative analyses showed that $\mathrm{Mg}$ deficiency increased hepatic concentrations of $\mathrm{Fe}(P<0.01), \mathrm{Cu}(P<0.01)$, Zn $(P<0.05), \mathrm{Zr}(P<0.01)$, and Mo $(P<0.01)$ (Table 2), which was consistent with the results obtained by the semi-quantitative analysis. Additionally, hepatic Sc concentration tended to lower $(P=$ $0.08)$ in the Mg-deficient rats.

We compared these mineral concentrations to those determined by the semiquantitative method (Fig 1). The semiquantitative measurements were well correlated with the quantitative measurements in these minerals ( $r>0.83$ in each mineral). On the other hand, the slop of correlating equation ranged between 0.38 and 1.99 . These results indicated that the semiquantitative analysis can detect the difference of each mineral concentration in the liver, but the accurate concentration is not obtained by this analysis.

Therefore, we consider that the semiquantitative method is a valid method for qualitatively assessing the difference of mineral concentrations and the quantitative analysis should be performed for obtaining accurate concentrations of minerals in animal tissues.

Many researchers reported that $\mathrm{Mg}$ deficiency increased hepatic Fe [4-7] and $\mathrm{Zn}[4,7,14]$ concentrations in rats, which were consistent with the present experiment. The effect of $\mathrm{Mg}$ deficiency on hepatic $\mathrm{Cu}$ concentration was controversial; Kimura and Itokawa [4] reported lower hepatic $\mathrm{Cu}$ in Mg-deficient rats but Jiménez et al. [8] indicated the higher $\mathrm{Cu}$ concentration in several tissues 
including the liver in Mg-deficient rats. The present study supported the report of Jiménez et al. [8]. To our knowledge, this is the first report demonstrating that Mg deficiency increases $\mathrm{Ga}, \mathrm{Y}, \mathrm{Zr}$, Mo, $\mathrm{Rh}, \mathrm{Ag}$, and $\mathrm{Ba}$ concentrations and decreases $\mathrm{Sc}$ and $\mathrm{Nb}$ concentrations in the liver.

We did not clarify how $\mathrm{Mg}$ deficiency increases many mineral concentrations in the liver. However, we speculate that $\mathrm{Mg}$ deficiency increases some mineral concentrations in the liver through increasing absorption of minerals. The liver is the first organ that receives minerals after absorption. Magnesium deficiency was reported to enhance the absorption of Fe [6] and Zn [15]. Additionally, magnesium deficiency was suggested to increase permeability of intercellular junctions of intestine [16], leading to increase $\mathrm{Cu}$ absorption [8]. Kimura et al. [17] indicated that $\mathrm{Mg}$ deficiency increased many ultra trace elements in rat plasma. Thus, the absorption of some minerals is possibly enhanced by increasing intestinal permeability in Mg deficient rats, resulting in increasing hepatic concentration of these minerals. The Mo requirement of rats was suggested as $0.2 \mathrm{mg} / \mathrm{kg}$, and Mo concentration in many organs including the liver was relatively stable in rats given Mo ranging from $0.1 \mathrm{mg} / \mathrm{kg}$ to 0.8 $\mathrm{mg} / \mathrm{kg}$ [18]. Further, Mo was efficiently absorbed as high as $90 \%$ in humans, and most of Mo absorbed is excreted in urine [19], indicating that Mo homeostasis is maintained by its excretion in urine. Therefore, $\mathrm{Mg}$ deficiency possibly decreases urinary Mo excretion, which increases hepatic Mo concentrations.

In conclusions, the semiquantitative analysis of ICP-MS is valid for qualitatively assessing the difference of mineral concentrations and the quantitative methods are necessary for obtaining accurate concentrations of minerals in animal tissues. Magnesium deficiency increases hepatic concentrations of essential trace minerals, such as $\mathrm{Fe}, \mathrm{Cu}, \mathrm{Zn}$, and Mo, and nonessential trace minerals, such as $\mathrm{Ga}, \mathrm{Y}$, $\mathrm{Zr}, \mathrm{Rh}, \mathrm{Ag}$, and $\mathrm{Ba}$. Further, hepatic concentrations of nonessential trace minerals $\mathrm{Sc}$ and $\mathrm{Nb}$ were decreased by Mg deficiency. 


\section{Acknowledgements}

The authors thank Emeritus Professor Yoshinori Itokawa and former Associate Professor Mieko Kimura of Division of Social and Preventive Medicine, Graduate School of Medicine, Kyoto University for giving us a chance to use ICP-MS.

\section{References}

1. O'Dell BL (1989) Mineral interactions relevant to nutrient requirement. J Nutr 119:1832-1838

2. Sherman AR, Tissue NT (1981) Tissue iron, copper and zinc levels in offspring of iron-sufficient and iron-deficient rats. J Nutr 111:266-275

3. Planells E, Sánchez-Morito N, Montellano MA, Aranda P, Llopis J (2000) Effect of magnesium deficiency on enterocyte $\mathrm{Ca}, \mathrm{Fe}, \mathrm{Cu}, \mathrm{Zn}, \mathrm{Mn}$ and Se content. J Physiol Biochem 56:217-222

4. Kimura M, Itokawa Y (1989) Inefficient utilization of iron and minerals in magnesium deficient rats. In: Itokawa Y, Durlach J (eds) Magnesium in Health and Disease. John Libbey, London, UK $95-102$

5. Takeda R, Nakamura T (2008) Effects of high magnesium intake on bone mineral status and lipid metabolism in rats. J Nutr Sci Vitaminol 54:66-75

6. Sanchez-Morito N, Planells E, Aranda P, Llopis J (2000) Influence of magnesium deficiency on the bioavailability and tissue distribution of iron in the rat. J Nutr Biochem 11:103-108

7. Vormann J, Günther T, Höllriegl V, Schümann K (1995) Effect of various degrees and duration of magnesium deficiency on lipid peroxidation and mineral metabolism in rats. J Nutr Biochem 6:681-688

8. Jiménez A, Planells E, Aranda P, Sánchez-Viñas M, Llopis, J (1997) Changes in bioavailability and tissue distribution of copper caused by magnesium deficiency in rats. J Agric Food Chem $45: 4023-4027$

9. Coedo AG, Dorado T, Padilla I, Fernandez BJ (2000) Spark ablation inductively coupled plasma 
mass spectrometry applied to the semi-quantitative panoramic analysis of ferroalloys. Applied Spectroscopy 54:1032-1039

10. Reeves PG (1997) Components of the AIN-93 diets as improvements in the AIN-76A diet. J Nutr $127: 838 S-841 S$

11. McCoy H, Kenney MA (1992) Magnesium and immune function: recent findings. Magnes Res $5: 281-293$

12. Weglicki WB, Phillips TM (1992) Pathobiology of magnesium deficiency: a cytokine/neurogenic inflammation hypothesis. Am J Physiol 263:R734-R737

13. Mazur A, Maier JA, Rock E, Gueux E, Nowacki W, Rayssiguier Y (2007) Magnesium and the inflammatory response: potential physiopathological implications. Arch Biochem Biophys 458:48-56

14. Mills BJ, Broghamer WL, Higgins PJ, Lindeman RD (1984) Inhibition of tumor growth by magnesium depletion of rats. J Nutr 114:739-745

15. Planells E, Aranda P, Lerma A, Llopis J (1994) Changes in bioavailability and tissue distribution of zinc caused by magnesium deficiency in rats. Br J Nutr 72:315-323

16. Cassidy MM, Tidball CS (1967) Cellular mechanism of intestinal permeability: alterations produced by chelation depletion. J Cell Biol 32:685-698

17. Kimura M, Honda K, Takeda A, Imanishi M, Takeda T (2004) Developed determination method of ultra trace elements and ultra trace element levels in plasma of rat fed low magnesium diet. $\mathrm{J}$ Am Coll Nutr 23:748S-750S

18. Wang X, Oberleas D, Yang MT, Yang SP (1992) Molybdenum requirement of female rats. J Nutr $122: 1036-1041$

19. Yoshida M, Hattori H, Ôta S, Yoshihara K, Kodama N, Yoshitake Y, Nishimuta M (2006) Molybdenum balance in healthy young Japanese women. J Trace Elem Med Biol 20:245-252 
Table 1. Effect of magnesium deficiency on hepatic mineral concentrations determined by the semi-quantitative analysis

\begin{tabular}{lccc|lccc}
\hline Mineral & Unit & Control & Mg deficiency & Mineral & Unit & Control & Mg deficiency \\
\hline Magnesium & $\mathrm{mg} / \mathrm{kg}$ & $386 \pm 22$ & $373 \pm 15$ & Arsenic & $\mu \mathrm{g} / \mathrm{kg}$ & $135 \pm 53$ & $99 \pm 32$ \\
Aluminum & $\mathrm{mg} / \mathrm{kg}$ & $17.7 \pm 1.9$ & $17.2 \pm 4.3$ & Rubidium & $\mathrm{mg} / \mathrm{kg}$ & $3.10 \pm 0.35$ & $3.24 \pm 0.20$ \\
Silicon & $\mathrm{mg} / \mathrm{kg}$ & $121 \pm 11$ & $138 \pm 16$ & Strontium & $\mu \mathrm{g} / \mathrm{kg}$ & $295 \pm 85$ & $592 \pm 649$ \\
Phosphorus & $\mathrm{g} / \mathrm{kg}$ & $1.53 \pm 0.11$ & $1.57 \pm 0.10$ & Yttrium & $\mu \mathrm{g} / \mathrm{kg}$ & $1.13 \pm 0.44$ & $1.78 \pm 0.43^{*}$ \\
Sulfur & $\mathrm{g} / \mathrm{kg}$ & $4.58 \pm 3.34$ & $3.78 \pm 1.92$ & Zirconium & $\mu \mathrm{g} / \mathrm{kg}$ & $108 \pm 45$ & $214 \pm 52^{* *}$ \\
Chlorine & $\mathrm{g} / \mathrm{kg}$ & $54.4 \pm 33.6$ & $42.5 \pm 25.7$ & Niobium & $\mu \mathrm{g} / \mathrm{kg}$ & $24.3 \pm 1.5$ & $22.2 \pm 1.4^{*}$ \\
Scandium & $\mu \mathrm{g} / \mathrm{kg}$ & $213 \pm 72$ & $124 \pm 61^{*}$ & Molybdenum & $\mu \mathrm{g} / \mathrm{kg}$ & $478 \pm 41$ & $587 \pm 30^{* *}$ \\
Titanium & $\mathrm{mg} / \mathrm{kg}$ & $8.60 \pm 0.61$ & $10.57 \pm 5.38$ & Ruthenium & $\mu \mathrm{g} / \mathrm{kg}$ & $0.063 \pm 0.099$ & $0.047 \pm 0.056$ \\
Vanadium & $\mu \mathrm{g} / \mathrm{kg}$ & $161 \pm 68$ & $223 \pm 40$ & Rhodium & $\mu \mathrm{g} / \mathrm{kg}$ & $0.064 \pm 0.042$ & $0.137 \pm 0.052^{*}$ \\
Chromium & $\mathrm{mg} / \mathrm{kg}$ & $1.54 \pm 1.80$ & $1.13 \pm 1.35$ & Palladium & $\mu \mathrm{g} / \mathrm{kg}$ & $0.651 \pm 0.206$ & $0.771 \pm 0.273$ \\
Manganese & $\mathrm{mg} / \mathrm{kg}$ & $3.15 \pm 0.42$ & $3.09 \pm 0.32$ & Silver & $\mu \mathrm{g} / \mathrm{kg}$ & $0.46 \pm 0.33$ & $1.72 \pm 0.44^{* *}$ \\
Iron & $\mathrm{mg} / \mathrm{kg}$ & $118 \pm 18$ & $168 \pm 28^{* *}$ & Cadmium & $\mu \mathrm{g} / \mathrm{kg}$ & $3.13 \pm 0.49$ & $3.10 \pm 0.51$ \\
Cobalt & $\mu \mathrm{g} / \mathrm{kg}$ & $15.8 \pm 7.9$ & $17.0 \pm 5.8$ & Tin & $\mu \mathrm{g} / \mathrm{kg}$ & $11.0 \pm 2.2$ & $15.5 \pm 13.1$ \\
Nickel & $\mu \mathrm{g} / \mathrm{kg}$ & $336 \pm 362$ & $384 \pm 362$ & Antimony & $\mu \mathrm{g} / \mathrm{kg}$ & $70.9 \pm 20.1$ & $58.4 \pm 22.8$ \\
Copper & $\mathrm{mg} / \mathrm{kg}$ & $6.65 \pm 0.61$ & $9.05 \pm 1.42^{* *}$ & Iodine & $\mu \mathrm{g} / \mathrm{kg}$ & $83.2 \pm 37.5$ & $64.9 \pm 14.5$ \\
Zinc & $\mathrm{mg} / \mathrm{kg}$ & $41.5 \pm 3.6$ & $48.0 \pm 2 . *^{* *}$ & Cesium & $\mu \mathrm{g} / \mathrm{kg}$ & $0.916 \pm 0.262$ & $0.989 \pm 0.109$ \\
Gallium & $\mu \mathrm{g} / \mathrm{kg}$ & $90.0 \pm 9.1$ & $102.1 \pm 7.3^{*}$ & Barium & $\mathrm{mg} / \mathrm{kg}$ & $3.67 \pm 0.73$ & $4.91 \pm 0.60^{*}$ \\
Germanium & $\mu \mathrm{g} / \mathrm{kg}$ & $1.20 \pm 0.71$ & $1.13 \pm 0.91$ & Lead & $\mu \mathrm{g} / \mathrm{kg}$ & $160 \pm 122$ & $238 \pm 201$ \\
\hline
\end{tabular}

Means \pm SD for six rats.

*, $P<0.05$; **, $P<0.01$; significantly different from the control group. 
Table 2. Effect of Mg deficiency on hepatic mineral concentrations determined by the quantitative analyses

\begin{tabular}{lccc}
\hline Mineral & Unit & Control & Mg deficiency \\
\hline Scandium & $\mu \mathrm{g} / \mathrm{kg}$ & $117 \pm 33$ & $84 \pm 25$ \\
Iron & $\mathrm{mg} / \mathrm{kg}$ & $87.8 \pm 14.2$ & $148.1 \pm 36.4^{* *}$ \\
Copper & $\mathrm{mg} / \mathrm{kg}$ & $4.02 \pm 0.59$ & $6.11 \pm 0.93^{* *}$ \\
Zinc & $\mathrm{mg} / \mathrm{kg}$ & $27.2 \pm 2.7$ & $30.6 \pm 2.5^{*}$ \\
Zirconium & $\mu \mathrm{g} / \mathrm{kg}$ & $270 \pm 69$ & $490 \pm 112^{* *}$ \\
Molybdenum & $\mu \mathrm{g} / \mathrm{kg}$ & $440 \pm 50$ & $530 \pm 40^{* *}$ \\
\hline
\end{tabular}

Mean \pm SD for six rats.

$* P<0.05$, ** $P<0.01$; significantly different from the control group. 

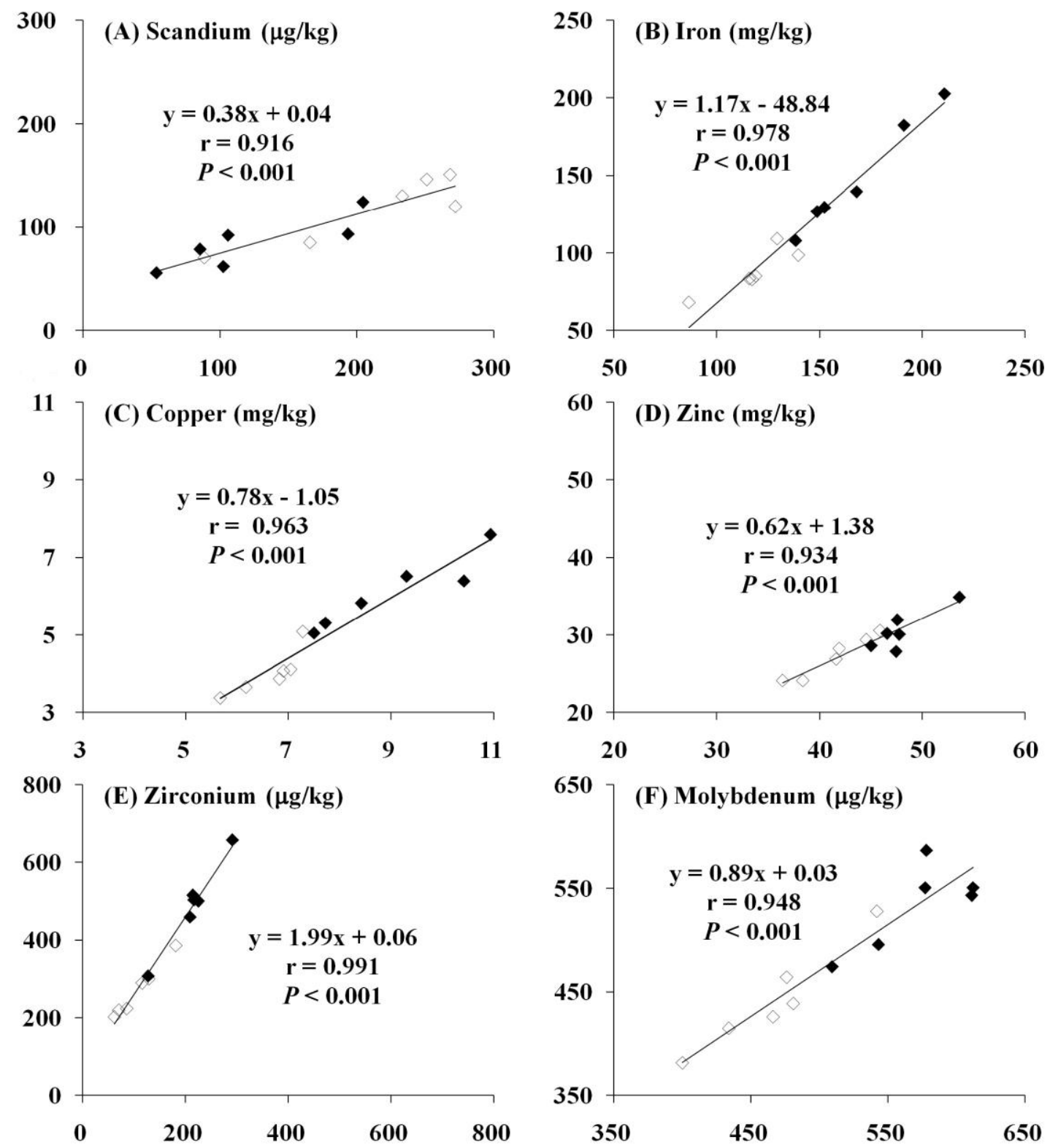

Figure 1. Correlations between semiquantitative measurements and quantitative measurements of some trace minerals. $(\diamond)$ and $(\diamond)$ showed control and magnesium deficient rats, respectively. The $x$ - and $y$-axis showed the concentration determined by the semiquantitative analysis and the quantitative analyses, respectively. $P$ values are significant level of correlations between semiquantitative measurements and quantitative measurements. 